\title{
9785_ENG
}

\section{A search for connections of gravitational influence of the Moon and the Sun with earthquakes of Carpathian region of Ukraine}

*A. Kazantsev, L. Kazantseva (Taras Shevchenko National University of Kyiv)

SUMMARY

If there is an influence of the Moon and Sun on the occurrence of earthquakes, the physical nature of such influence can only be the gravitational. A possible gravitational influence is caused by the resultant tidal forces of the Moon and the Sun, but not by their separate actions. The calculations algorithm for the tidal forces of the Sun and Moon and for their resultant is described. Relative changes of these forces for different zones on the earth's surface in time and at various depths are presented. Preliminary recommendations for searching of connections of gravitational influence of the Moon and the Sun with earthquakes was made.

\section{Підхід до пошуку зв'язків гравітаційного впливу Місяця й Сонця із землетрусами}

*А.М. Казанцев, Л.В. Казанцева (Київський національний університет імені Тараса Шевченка) PEЗЮME

Якщо існує вплив Місяця й Сонця на виникнення землетрусів, то фізична природа такого впливу може бути лише гравітаційною. Можливий гравітаційний вплив викликає рівнодійна припливних сил Місяця й Сонця, а не їх окрема дія. Описано алгоритм обчислення припливних сил Місяця й Сонця та їх рівнодійної. Наведено відносні зміни цих сил з часом для різних точок земної поверхні та на різних глибинах. Зроблені попередні рекомендації по пошуках зв'язків гравітаційного впливу Місяця й Сонця із землетрусами. 


\section{Introduction}

If there is an influence of the Moon and Sun on the occurrence of earthquakes, the physical nature of such influence can only be the gravitational. A possible gravitational influence is caused by the resultant tidal forces of the Moon and the Sun, but not by their separate actions. Therefore, any connections the Moon and the Sun with earthquakes should look for on parameters of the resultant tidal force (size, direction, temporal and spatial changes, etc.). The gravitational influence of the Moon and Sun on the occurrence of earthquakes can be seen as a trigger for the release of energy in the hypocenter accumulated by independent underground processes.

\section{Method and theory}

To calculate the tidal forces of the Sun and the Moon was used the well-known modern program DE406 / LE406. Besides additional programs to calculate certain parameters, which can not be obtain directly from the DE406 / LE406 were produced. There were calculated tidal forces of the Moon $\boldsymbol{F}_{\mathrm{tM}}$ and the Sun $\boldsymbol{F}_{\mathrm{tS}}$ and their resultant force $\boldsymbol{F}_{\mathrm{MS}}$ for different latitudes (from $90^{\circ}$ to $-90^{\circ}$ ) and for different hypocenter depths (from 0 to $700 \mathrm{~km}$ ).

\section{The calculation results}

Tidal force of the Moon sometimes 5 times exceeds the solar one, and sometimes these forces are almost equal (Fig. 1). On the $\mathrm{X}$ axis the Julian days reduced by 2450000 are pointed.

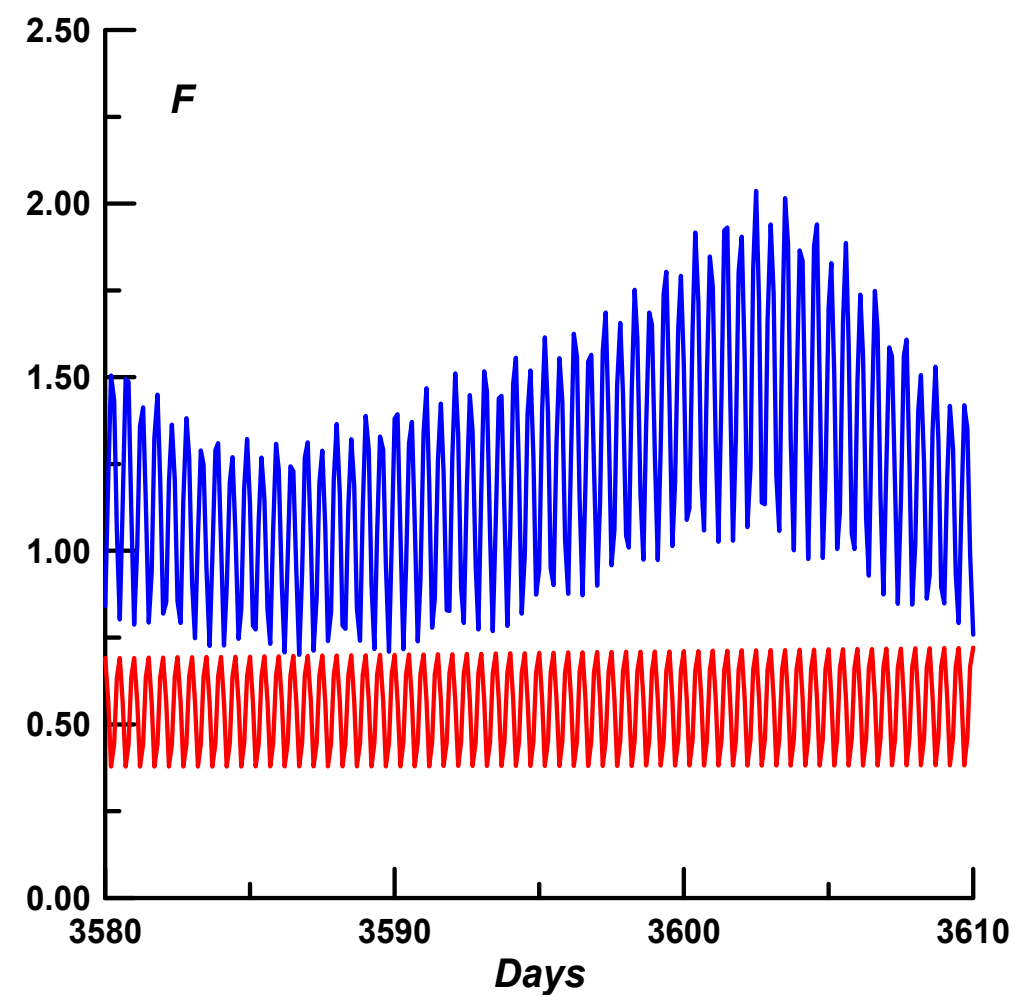

Figure 1 Changes of tidal forces (in relative units) of the Moon (blue line) and the Sun (red line) during a month at a latitude of $0^{\circ}$. 
The size of changing of $\boldsymbol{F}_{\mathrm{MS}}$ is significantly different at different latitudes. At low latitudes $\left( \pm 25^{\circ}\right)$ in a point on the surface of the Earth the maximum value of resultant force may exceed the minimum of 40 times, at the polar latitudes (higher $85^{\circ}$ and lower $-85^{\circ}$ ) - less than two-fold (Fig. 2).

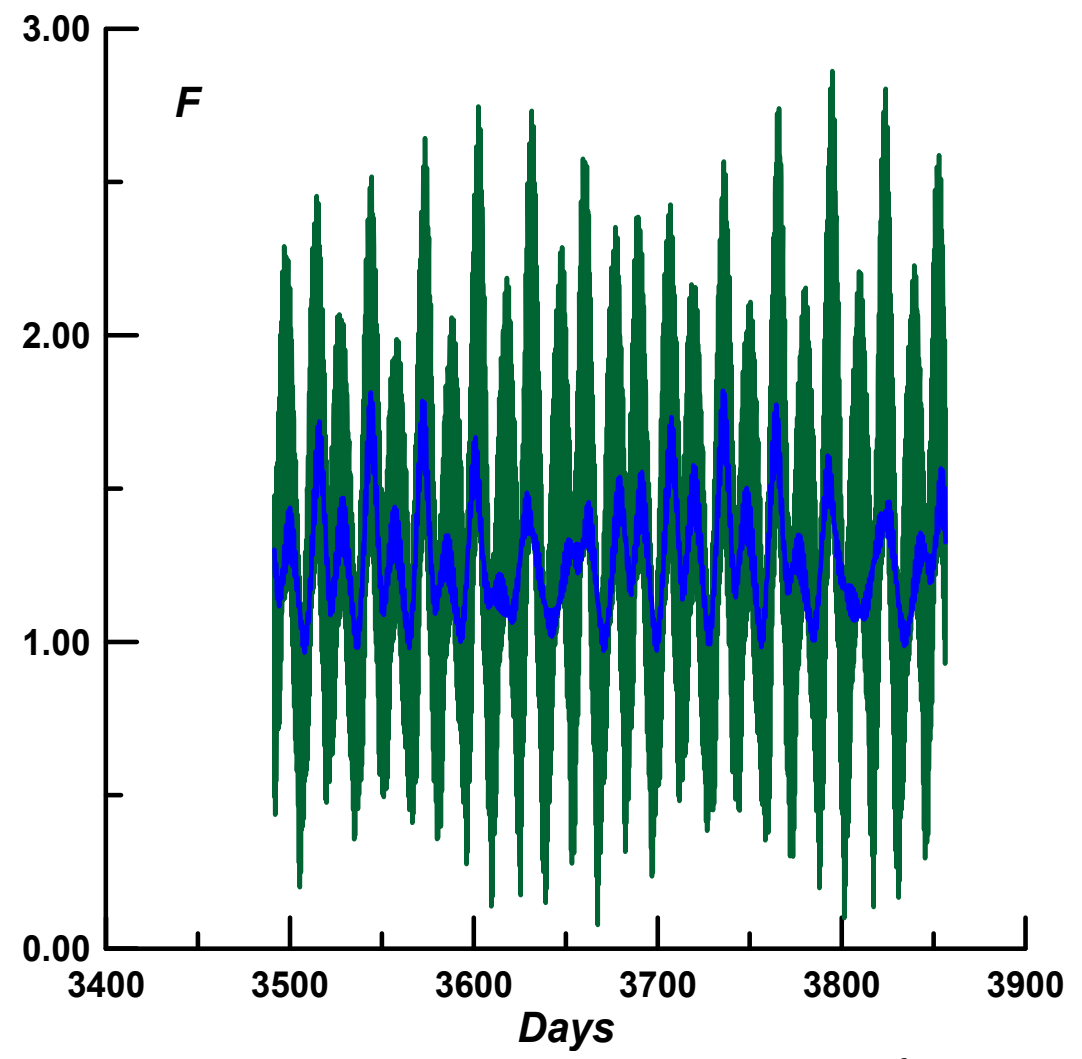

Figure 2 Changes of resultant force $\boldsymbol{F}_{\mathrm{MS}}$ (in relative units) at latitude of $0^{\circ}$ (green line) and at latitude of $85^{\circ}$ (blue line) during a year.

The greatest values of the $\boldsymbol{F}_{\mathrm{MS}}$ take place in the latitudes range of $\pm 30^{\circ}$.

In areas near the poles (higher $80^{\circ}$ and lower $-80^{\circ}$ ) the resultant force is constantly directed into the ground.

Tidal forces, like their resultant decrease with depth. At depths of $700 \mathrm{~km}$ resultant force is by $12 \%$ lower than at the surface.

\section{Conclusions}

One can assume that the influence of the Sun and Moon on the earthquakes will be stronger acts in the relatively lower depths and outside the polar areas of the Earth. To identify real physical influence of the Sun and the Moon on occurrence of earthquakes it is advisable to analyze parameters of the resultant force in the moments of the events in separate hypocenters. For that it is necessary to have the most comprehensive array of earthquake data in a hypocenter and accurate calculated resultant tidal forces. 